\title{
Diurnal Characteristics of Ecosystem Respiration of Alpine Meadow on the Qinghai-Tibetan Plateau: Implications for Carbon Budget Estimation
}

\author{
Yu Qin and Shuhua Yi \\ State Key Laboratory of Cryospheric Sciences, Cold and Arid Regions Environmental and Engineering Research Institute, \\ Chinese Academy of Sciences, 320 Donggang West Road, Lanzhou 730000, China
}

Correspondence should be addressed to Shuhua Yi; yis@lzb.ac.cn

Received 6 May 2013; Accepted 12 June 2013

Academic Editors: D. M. Lloyd and L. Olsvig-Whittaker

Copyright (C) 2013 Y. Qin and S. Yi. This is an open access article distributed under the Creative Commons Attribution License, which permits unrestricted use, distribution, and reproduction in any medium, provided the original work is properly cited.

\begin{abstract}
Accurately estimating daily mean ecosystem respiration rate $(\mathrm{Re})$ is important for understanding how ecosystem carbon budgets will respond to climate change. Usually, daily mean Re is represented by measurement using static chamber on alpine meadow ecosystems from 9:00 to 11:00 h a.m. local time directly. In the present study, however, we found that the calculated daily mean Re from 9:00 to 11:00 h a.m. local time was significantly higher than that from 0:00 to 23:30 h local time in an alpine meadow site, which might be caused by special climate condition on the Qinghai-Tibetan Plateau. Our results indicated that the calculated daily mean Re from 9:00 to 11:00 h a.m. local time cannot be used to represent daily mean Re directly.
\end{abstract}

\section{Introduction}

Great concerns over global warming and climate change have been proposed for improving the accuracy in estimating carbon flux in terrestrial ecosystems [1-3]. Static chamber method has widely been applied to measure ecosystem respiration in different ecosystems [4-6]. This method requires manual operation, therefore, it is a common practice to measure respirations of a period in a day to represent daily mean value, for example, 06:00-11:00 h a.m. [7], 9:00-11:00 h a.m. [8], and 14:00-16:00 h p.m [9]. Re measured between 9:00 and 11:00 h a.m. local time has been used to represent the daily mean value for the alpine meadow ecosystems on the Qinghai-Tibetan Plateau [10-15] and other ecosystems $[8,16,17]$. However, it is unknown whether this method is valid on the Qinghai-Tibetan Plateau, which has unique climate condition [18]. Therefore, in this study, we carried out round-the-clock field observation of ecosystem respiration per half-hour using an automated soil $\mathrm{CO}_{2}$ flux system to test this method.

The field measurement was carried out in an alpine meadow at 3,887 $\mathrm{m}$ a.s.l. in Shule River Basin at the southeast $45 \mathrm{~km}$ far away Suli county $\left(98^{\circ} 18^{\prime} 33.2^{\prime \prime}\right.$ E, $\left.38^{\circ} 25^{\prime \prime} 13.5^{\prime \prime} \mathrm{N}\right)$, the western part of Qilian Mountain, which is on the northeast edge of the Qinghai-Tibetan Plateau, Qinghai Province, China. The climate belongs to continental climate and is mainly controlled by westerly winds, with annual average precipitation being $200-400 \mathrm{~mm}$, of which nearly $90 \%$ falls in the growing season (May-September), and the annual mean temperature ranged from -4.0 to $-19.4^{\circ} \mathrm{C}$ [19]. Soils are classified as felty soils [20]. The study site, $\sim 100 \times 100 \mathrm{~m}^{2}$, has been fenced in 2010 to exclude the grazing activities of sheep and yaks. The dominant vegetations are Kobresia capillifolia and Carex moorcroftii. The permafrost type is transition according to the classified method by Cheng and Wang [21]. Three $2 \times 2 \mathrm{~m}^{2}$ plots were set up randomly for the measurement of ecosystem respiration, and all the selected plots were expected to be less in spatial heterogeneity by visual inspection of the vegetation. Half-hour Re values were measured every 3 to 15 days depending on weather conditions during the whole growing season (May-September) in 2012 using an automated soil $\mathrm{CO}_{2}$ flux system (LI-8150, LI-COR Biosciences, Lincoln, NE, USA) equipped with LI-COR8100-104 long-term chamber. Three polyvinyl chloride collars $20 \mathrm{~cm}$ in diameter and $12 \mathrm{~cm}$ in height were used for measurements. Collars were inserted into soil at $8-9 \mathrm{~cm}$. To reduce 

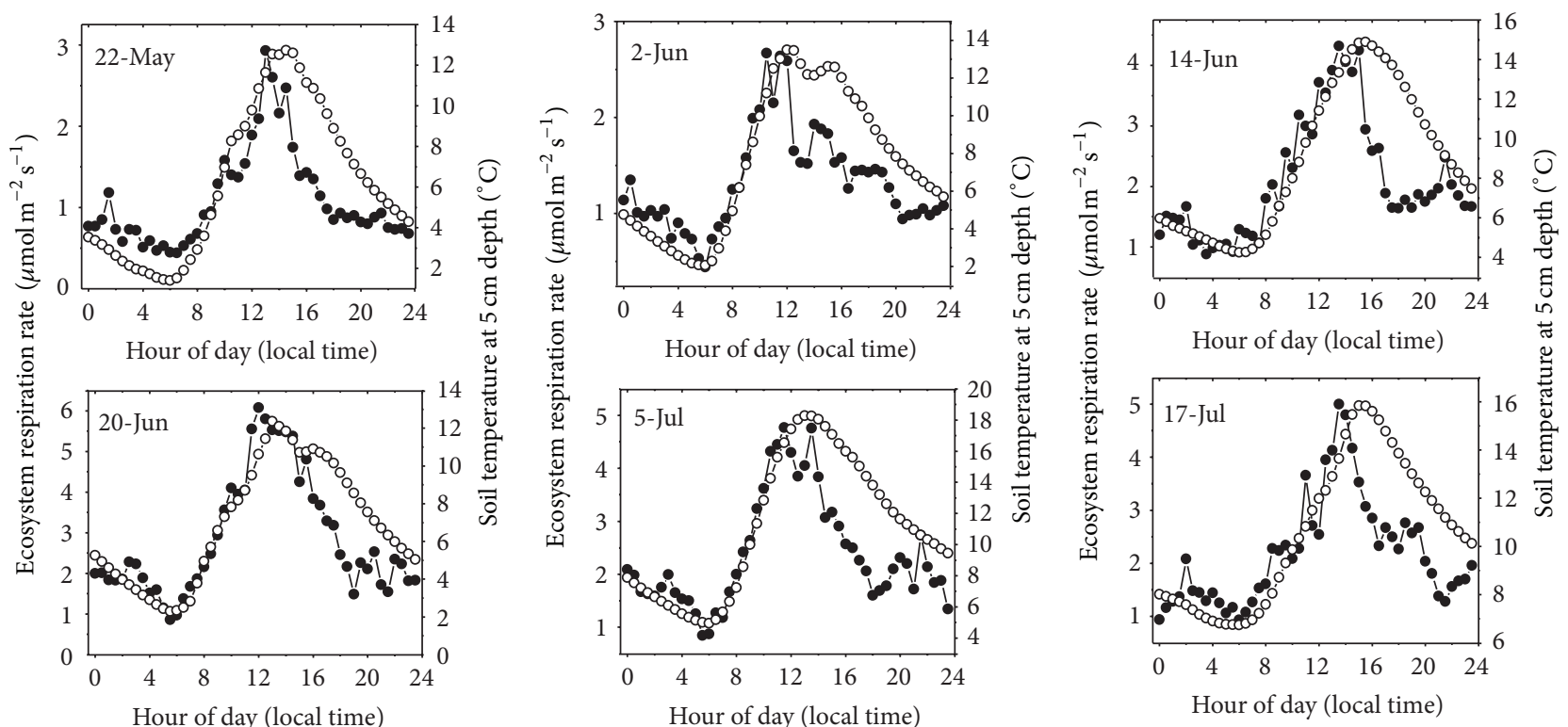

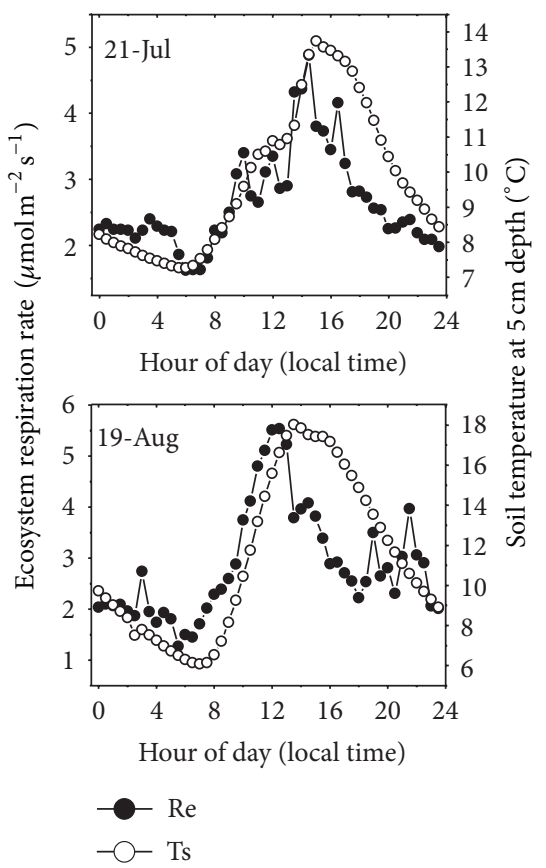

(a)

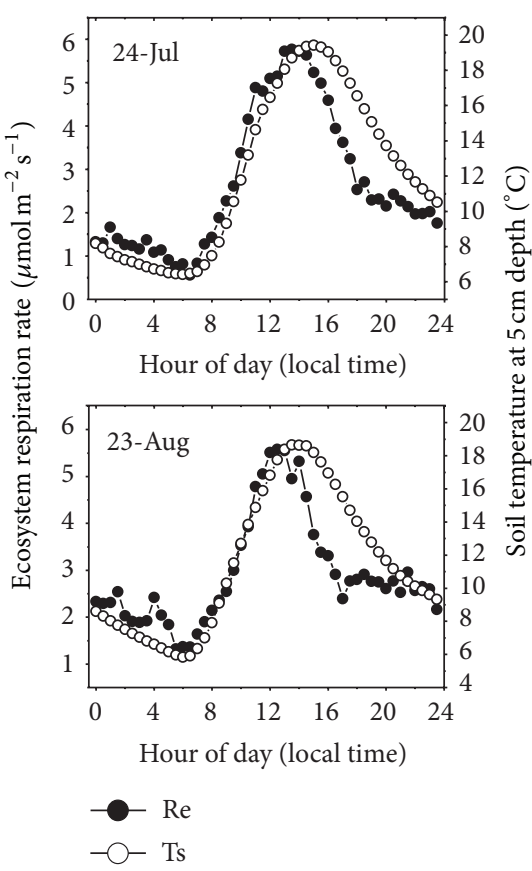

(b)

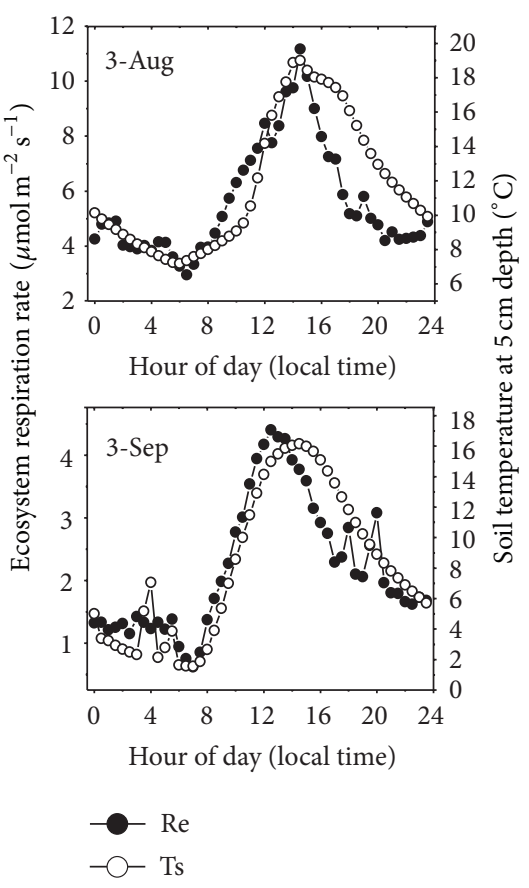

(c)

FIGURE 1: Diurnal variations of ecosystem respiration rate $\left(\mu \mathrm{moL} \mathrm{m}{ }^{-2} \mathrm{~s}^{-1}\right)$ and soil temperature at $5 \mathrm{~cm}$ depth $\left({ }^{\circ} \mathrm{C}\right)$ during the grown season from May to September.

a disturbance-induced $\mathrm{CO}_{2}$ efflux, all collars were installed $24 \mathrm{~h}$ prior to the first measurement. Soil temperature at $5 \mathrm{~cm}$ and moisture at $7 \mathrm{~cm}$ below soil surface were measured at each chamber simultaneously while Re was measured. To eliminate artifacts due to the Venturi effect [22], we excluded measured values of Re when wind speed exceeded $7.5 \mathrm{~m} \mathrm{~s}^{-1}$ according to $\mathrm{Xu}$ et al. [23]. Data of the half-hour wind speed was derived from the meteorological stations in our study site for the period of May to September, 2012. However, our exclusion can maintain the reliability of values because field observation supplied enough data for estimating daily mean Re.
The maximum and minimum Re values of ecosystem respiration occurred at 12:00 to $16: 00 \mathrm{~h} \mathrm{p.m}$. and 4:00 to 8:00 h a.m. local time, respectively (Figure 1), which corresponded well with the diurnal pattern of soil temperatures. Although the daily mean Re from 9:00 to 11:00 h a.m. local time was strongly correlated with that from 0:00 to 23:30 h (Figure 2), the calculated daily mean values of Re from 9:00 to 11:00 h a.m. local time were significantly higher than those from 0:00 to 23:00 h for both conditions with and without exclusion of wind effects (Table 1). Compared with daily mean values from 0:00 to 23:00 h, the Re values from 9:00 to 11:00 h a.m. local time were $23.90 \% / 24.08 \%$ greater than the daily mean values 
TABLE 1: Daily mean values of Re calculated from 9:00 to 11:00 h a.m. local time and from 0:00 to 23:00 h before and after exclusion of the effect of wind.

\begin{tabular}{|c|c|c|c|c|c|c|}
\hline \multirow{2}{*}{ Date } & \multicolumn{3}{|c|}{ Before exclusion of the effect of wind } & \multicolumn{3}{|c|}{ After exclusion of the effect of wind } \\
\hline & $0: 00-23: 30$ & 9:00-11:00 & Overestimate (\%) & 0:00-23:30 & 9:00-11:00 & Overestimation (\%) \\
\hline 22-May & 1.09 & 1.32 & 21.13 & 1.15 & 1.25 & 9.09 \\
\hline 02-Jun & 1.33 & 2.09 & 57.69 & 1.32 & 2.09 & 58.13 \\
\hline 14-Jun & 2.09 & 2.54 & 21.94 & 2.11 & 2.54 & 20.71 \\
\hline 20-Jun & 2.86 & 3.72 & 30.23 & 2.86 & 3.72 & 30.23 \\
\hline 05-Jul & 2.39 & 3.65 & 53.05 & 2.46 & 3.65 & 48.55 \\
\hline 17-Jul & 2.19 & 2.52 & 15.07 & 2.19 & 2.52 & 15.07 \\
\hline 21-Jul & 2.65 & 2.88 & 8.42 & 2.65 & 2.88 & 8.42 \\
\hline 24-Jul & 2.68 & 3.46 & 28.96 & 2.72 & 3.46 & 27.09 \\
\hline 03-Aug & 5.63 & 6.20 & 10.18 & 5.35 & 6.20 & 15.85 \\
\hline 19-Aug & 2.87 & 3.63 & 26.58 & 2.86 & 3.63 & 27.14 \\
\hline 23-Aug & 2.93 & 3.56 & 21.54 & 2.93 & 3.56 & 21.54 \\
\hline 03-Sep & 2.21 & 2.71 & 22.91 & 2.21 & 2.71 & 22.91 \\
\hline Mean & 2.58 & 3.19 & 23.90 & 2.57 & 3.19 & 24.08 \\
\hline
\end{tabular}

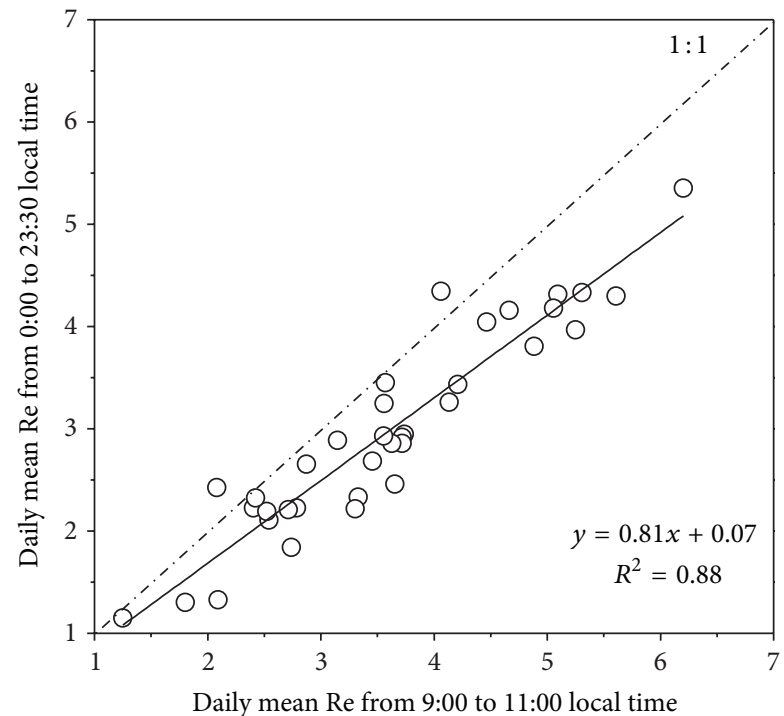

FIGURE 2: Relationships between the daily mean values of Re $\left(\mu \mathrm{moL} \mathrm{m}^{-2} \mathrm{~s}^{-1}\right)$ calculated from 0:00-23:00 $\mathrm{h}$ local time and the $\mathrm{Re}$ estimated by 9:00-11:00 h a.m. local time; all the measurements for three chambers for all the sampling dates were pooled together, $n=36$.

before/after exclusion the effects of wind during the whole growing season (Table 1).

Our results are consistent with Cao et al. [24] and Zhang et al. [25], whose results showed that diurnal variations of soil respiration on the alpine meadow presented significant single peak dynamics with the maximum value in 12:0016:00 h p.m. local time and the minimum value in 4:00-8:00 h a.m. local time by using static chamber. However, our results are inconsistent with Tang et al. [26] and Li et al. [27], who have demonstrated that $\mathrm{CO}_{2}$ fluxes measured at 9:00-11:00 h a.m. local time were close to daily means in subtropical forest ecosystem in southern China and in cropland ecosystem on the Loess Plateau in northern China. Those correlations that existed in forest and cropland ecosystems were associated with relatively low range of soil temperature and flat daily curves of $\mathrm{CO}_{2}$ fluxes during daytime and nighttime [28]. In the present study, daily mean Re calculated from 9:00 to $11: 00 \mathrm{~h}$ a.m. local time was significantly higher than 0:00 to $23: 30 \mathrm{~h}$ local time, which might be caused by special climate conditions on the Qinghai-Tibetan Plateau. The solar radiation can penetrate thin atmosphere easily to heat land surface, the soil temperature increases quickly after sunrise; the upward land surface longwave radiation can also dissipate quickly due to thin atmosphere, and surface soil temperature decreases quickly in the afternoon (Figure 3). Stronger diurnal variation of Re was apparent in this alpine meadow ecosystem, it is possible that daily mean Re will be overestimated if it is represented by Re of any period during daytime. To improve the accuracy in estimation of carbon budget, hence, automated continuous all-day field observation for Re initiated here will provide more definitive studies [29, 30]. Compared with static chamber, automated soil $\mathrm{CO}_{2}$ flux system can measure wide temporal variability in ecosystem respiration with the range from half-hour to seasonal and even to interannual [31]. An alternative way is to calculate the ratios of instant Re from 9:00-11:00 a.m. local time to the daily mean $\mathrm{Re}$ and then to use these ratios to calculate daily mean $\operatorname{Re}[32]$.

\section{Authors' Contribution}

Shuhua Yi contributed to experiment design and paper revision. Yu Qin contributed to field data collection, data analysis, and paper writing.

\section{Acknowledgments}

The authors acknowledge Shilong Ren, Jianjun Chen, and Xiaoyun Wang for for their help with the fieldwork and Professors Tianding Han, Jinkui $\mathrm{Wu}$, and $\mathrm{HaO} \mathrm{Wu}$ for providing meteorological data. This study was jointly supported through Grants of the Major State Basic Research 


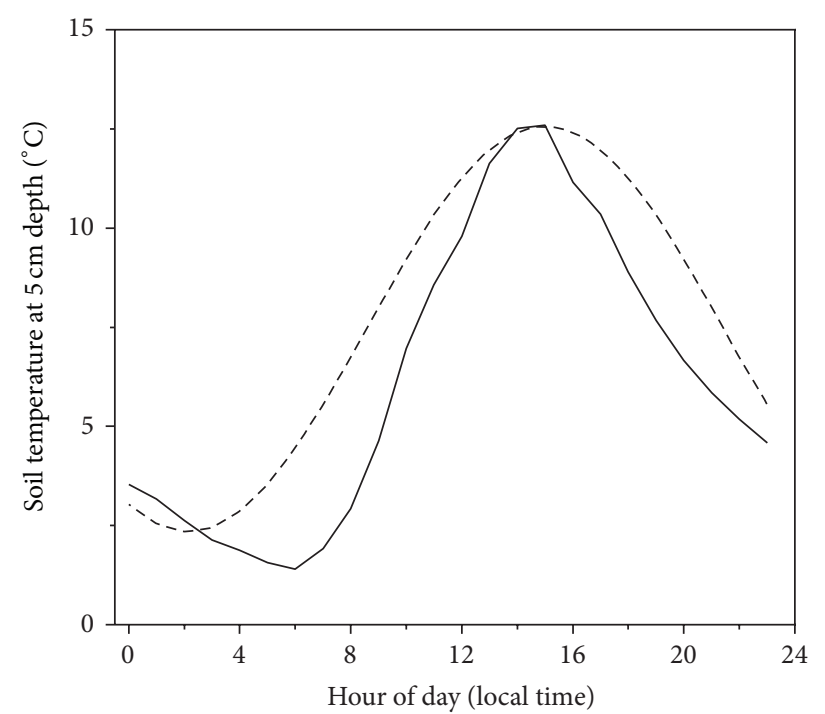

(a)

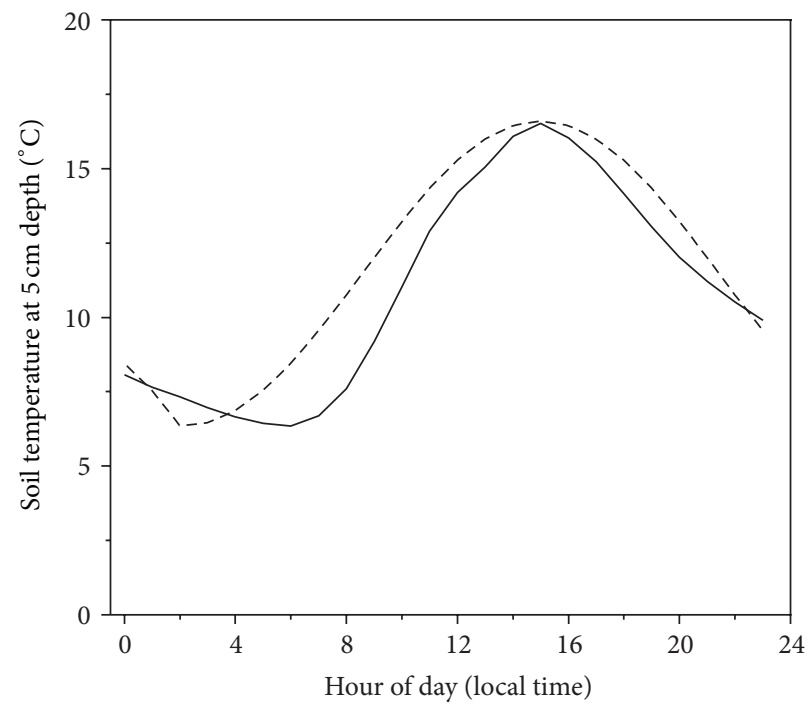

(c)

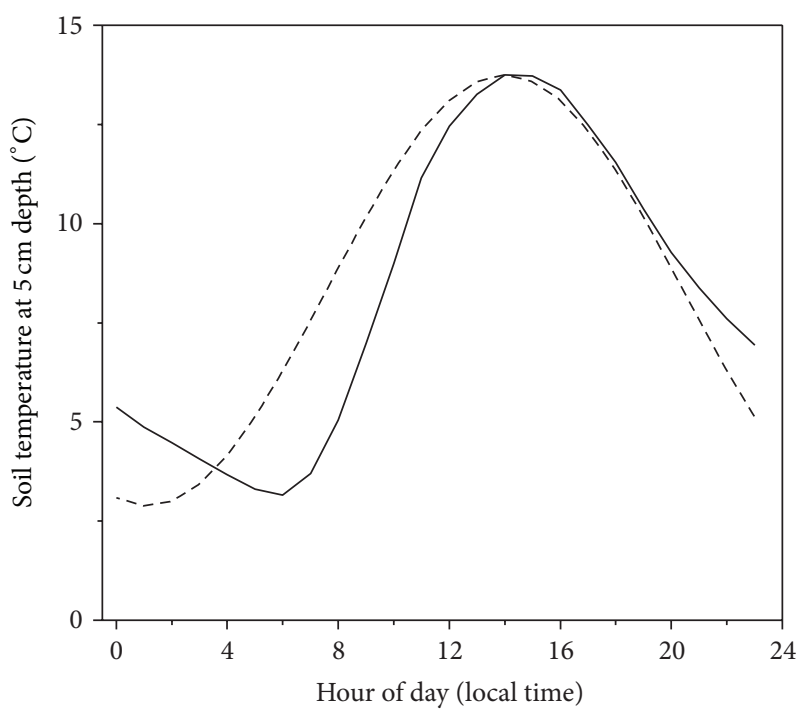

(b)

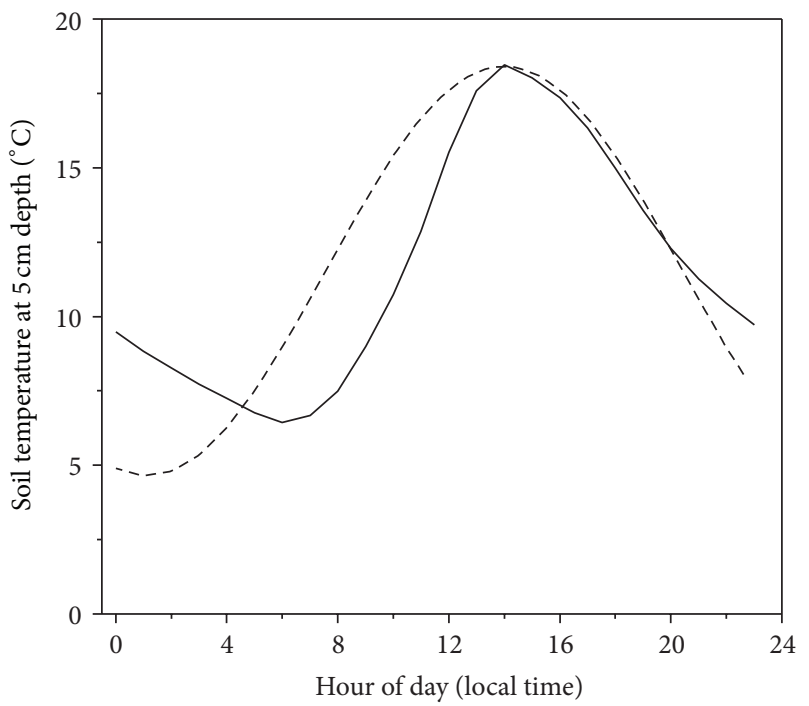

(d)

FIGURE 3: Comparison between 3-day daily mean diurnal soil temperature (solid line, $5 \mathrm{~cm}$ ) and the corresponding sinusoidal temperature (dashed line) with the same daily range for May (a), June (b), July (c), and August (d).

Development Programme of China (973 Programme) (no. 2010CB951402), the Strategic Priority Research Program (XDB030303) and One Hundred People Plan (O927581001) of the Chinese Academy of Sciences, and the Chinese National Natural Science Foundation Commission (41271089), as well as independent Grants from State Key Laboratory of Cryospheric Sciences (SKLCS-ZZ-2012-2-2).

\section{References}

[1] D. S. Schimel, "Terrestrial ecosystems and the carbon cycle," Global Change Biology, vol. 1, no. 1, pp. 77-91, 1995.

[2] R. A. Houghton, "Balancing the global carbon budget," Annual Review of Earth and Planetary Sciences, vol. 35, pp. 313-347, 2007.
[3] M. Heimann and M. Reichstein, "Terrestrial ecosystem carbon dynamics and climate feedbacks," Nature, vol. 451, no. 7176, pp. 289-292, 2008.

[4] J. W. Raich, C. S. Potter, and D. Bhagawati, "Interannual variability in global soil respiration, 1980-94," Global Change Biology, vol. 8, no. 8, pp. 800-812, 2002.

[5] A. Heinemeyer and N. P. McNamara, "Comparing the closed static versus the closed dynamic chamber flux methodology: implications for soil respiration studies," Plant and Soil, vol. 346, no. 1, pp. 145-151, 2011.

[6] S. Olajuyigbe, B. Tobin, M. Saunders, and M. Nieuwenhuis, "Forest thinning and soil respiration in a Sitka spruce forest in Ireland," Agricultural and Forest Meteorology, vol. 157, pp. 86-95, 2012.

[7] C. E. Hicks Pries, E. A. G. Schuur, and K. G. Crummer, "Thawing permafrost increases old soil and autotrophic respiration 
in tundra: partitioning ecosystem respiration using $\delta^{13} \mathrm{C}$ and $\Delta^{14}$ C," Global Change Biology, vol. 19, no. 2, pp. 649-661, 2013.

[8] J. Priess and H. Fölster, "Carbon cycle dynamics and soil respiration of forest under natural degradation in the Gran Sabana," Interciencia, vol. 19, pp. 317-322, 1994.

[9] B. Meda, C. R. Flechard, K. Germain, P. Robin, C. Walter, and M. Hassouna, "Greenhouse gas emissions from the grassy outdoor run of organic broilers," Biogeosciences, vol. 9, no. 4, pp. 14931508, 2012.

[10] J. Wang, G. Wang, Y. Wang, and Y. Li, "Influences of the degradation of swamp and alpine meadows on $\mathrm{CO}_{2}$ emission during growing season on the Qinghai-Tibet Plateau," Chinese Science Bulletin, vol. 52, no. 18, pp. 2565-2574, 2007 (Chinese).

[11] Q.-W. Hu, Q. Wu, G.-M. Cao, D. Li, R.-J. Long, and Y.-S. Wang, "Growing season ecosystem respirations and associated component fluxes in two alpine meadows on the Tibetan Plateau," Journal of Integrative Plant Biology, vol. 50, no. 3, pp. 271-279, 2008.

[12] C. Jiang, G. Yu, H. Fang, G. Cao, and Y. Li, "Short-term effect of increasing nitrogen deposition on $\mathrm{CO}_{2}, \mathrm{CH}_{4}$ and $\mathrm{N}_{2} \mathrm{O}$ fluxes in an alpine meadow on the Qinghai-Tibetan Plateau, China," Atmospheric Environment, vol. 44, no. 24, pp. 2920-2926, 2010.

[13] X. Lin, S. Wang, X. Ma et al., "Fluxes of $\mathrm{CO}_{2}, \mathrm{CH}_{4}$, and $\mathrm{N}_{2} \mathrm{O}$ in an alpine meadow affected by yak excreta on the QinghaiTibetan plateau during summer grazing periods," Soil Biology and Biochemistry, vol. 41, no. 4, pp. 718-725, 2009.

[14] X. Lin, Z. Zhang, S. Wang et al., "Response of ecosystem respiration to warming and grazing during the growing seasons in the alpine meadow on the Tibetan plateau," Agricultural and Forest Meteorology, vol. 151, no. 7, pp. 792-802, 2011.

[15] Z. H. Zhang, J. C. Duan, S. P. Wang et al., "Effects of seeding ratios and nitrogen fertilizer on ecosystem respiration of common vetch and oat on the Tibetan plateau," Plant Soil, vol. 362, pp. 287-299, 2013.

[16] T. Zhu, S. Cheng, H. Fang, G. Yu, J. Zheng, and Y. Li, "Early responses of soil $\mathrm{CO}_{2}$ emission to simulating atmospheric nitrogen deposition in an alpine meadow on the Qinghai Tibetan Plateau," Acta Ecologica Sinica, vol. 31, no. 10, pp. 26872696, 2011 (Chinese).

[17] M. A. Liebig, S. L. Kronberg, J. R. Hendrickson, X. Dong, and J. R. Gross, "Carbon dioxide efflux from long-term grazing management systems in a semiarid region," Agriculture, Ecosystems and Environment, vol. 164, pp. 137-144, 2013.

[18] O. M. Raspopov, V. A. Dergachev, J. Esper et al., "The influence of the de Vries ( 200-year) solar cycle on climate variations: results from the Central Asian Mountains and their global link," Palaeogeography, Palaeoclimatology, Palaeoecology, vol. 259, no. 1, pp. 6-16, 2008.

[19] S. Yi, Z. Zhou, S. Ren et al., "Effects of permafrost degradation on alpine grassland in a semi-arid basin on the Qinghai-Tibetan Plateau," Environmental Research Letters, vol. 6, no. 4, Article ID 045403, 2011.

[20] W. J. Liu, S. Y. Chen, X. Qin et al., "Storage, patterns, and control of soil organic carbon and nitrogen in the northeastern margin of the Qinghai-Tibetan Plateau," Environmental Research Letters, vol. 7, no. 3, Article ID 035401, 2012.

[21] G. D. Cheng and S. L. Wang, "On the zonation of high altitude permafrost in China," Journal of Glaciology and Geocryology, vol. 4, pp. 1-17, 1982 (Chinese).

[22] F. Conen and K. A. Smith, "A re-examination of closed flux chamber methods for the measurement of trace gas emissions from soils to the atmosphere," European Journal of Soil Science, vol. 49, no. 4, pp. 701-707, 1998.

[23] L. Xu, M. D. Furtaw, R. A. Madsen, R. L. Garcia, D. J. Anderson, and D. K. McDermitt, "On maintaining pressure equilibrium between a soil $\mathrm{CO}_{2}$ flux chamber and the ambient air," Journal of Geophysical Research D, vol. 111, no. 8, Article ID D08S10, 2006.

[24] G. M. Cao, Y. N. Li, J. X. Zhang, and X. Q. Zhao, "Effect of soil circumstances biogeochemical factors on carbon dioxide emission from Mollic-Gryic Cambisols," Acta Agrestia Sinica, vol. 9, pp. 307-312, 2001 (Chinese).

[25] J. X. Zhang, G. M. Cao, D. W. Zhou, Q. W. Hu, and X. Q. Zhao, "The carbon storage and carbon cycle among the atmosphere, soil, vegetation and animal in the Kobresia humilis alpine meadow ecosystem," Acta Ecologica Sinica, vol. 23, pp. 627-633, 2003 (Chinese).

[26] X. Tang, S. Liu, G. Zhou, D. Zhang, and C. Zhou, "Soilatmospheric exchange of $\mathrm{CO}_{2}, \mathrm{CH}_{4}$, and $\mathrm{N}_{2} \mathrm{O}$ in three subtropical forest ecosystems in southern China," Global Change Biology, vol. 12, no. 3, pp. 546-560, 2006.

[27] X. Li, H. Fu, D. Guo, X. Li, and C. Wan, "Partitioning soil respiration and assessing the carbon balance in a Setaria italica (L.) Beauv. Cropland on the Loess Plateau, Northern China," Soil Biology and Biochemistry, vol. 42, no. 2, pp. 337-346, 2010.

[28] J. Yan, D. Zhang, G. Zhou, and J. Liu, "Soil respiration associated with forest succession in subtropical forests in Dinghushan Biosphere Reserve," Soil Biology and Biochemistry, vol. 41, no. 5, pp. 991-999, 2009.

[29] K. L. Thomas, J. Benstead, S. H. Lloyd, and D. Lloyd, "Diurnal oscillations of gas production and effluxes $\left(\mathrm{CO}_{2}\right.$ and $\left.\mathrm{CH}_{4}\right)$ in cores from a peat bog," Biological Rhythm Research, vol. 29, no. 3, pp. 247-259, 1998.

[30] S. K. Sheppard and D. Lloyd, "Diurnal oscillations in gas production $\left(\mathrm{O}_{2}, \mathrm{CO}_{2}, \mathrm{CH}_{4}\right.$, and $\left.\mathrm{N}_{2}\right)$ in soil monoliths," Biological Rhythm Research, vol. 33, no. 5, pp. 577-591, 2002.

[31] R. S. Jassal, T. A. Black, Z. Nesic, and D. Gaumont-Guay, "Using automated non-steady-state chamber systems for making continuous long-term measurements of soil $\mathrm{CO}_{2}$ efflux in forest ecosystems," Agricultural and Forest Meteorology, vol. 161, pp. 57-65, 2012.

[32] Y. Geng, Y. Wang, K. Yang et al., "Soil respiration in tibetan alpine grasslands: belowground biomass and soil moisture, but not soil temperature, best explain the large-scale patterns," PLoS One, vol. 7, no. 4, Article ID e34968, 2012. 

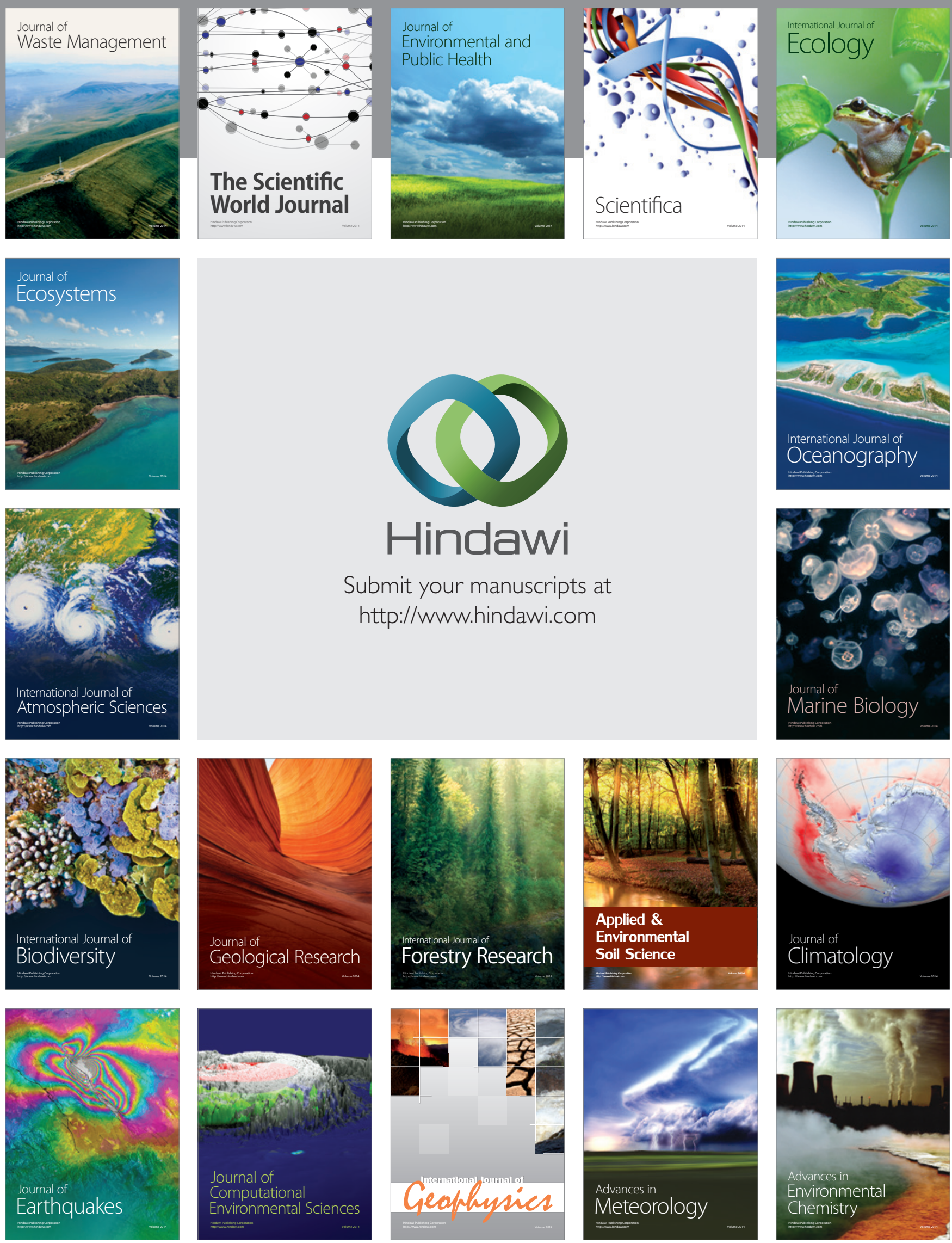